\title{
DIGLOSIA
}

Terakreditasi Sinta 3 | Volume 3 | Nomor 3 | Tahun 2020 | Halaman 263-276

P-ISSN 2615-725X | E-ISSN 2615-8655

http://diglosiaunmul.com/index.php/diglosia/article/view/80

\section{NAMA TOKOH SEBAGAI TEKS ACUAN \\ DALAM PENULISAN JUDUL PROGRAM KREATIVITAS MAHASISWA 5 BIDANG (STUDI PRIOR TEXT)}

\author{
Figure's Name as Text Reference in Writing Tittle of Program Kreativitas Mahasiswa 5 Bidang \\ (Prior Text Study) \\ Nivia Putri Ratna Juwita ${ }^{1, *}$, Atiqa Sabardila ${ }^{2}$, Markhamah ${ }^{3}$ \\ ${ }^{1,2,3}$ Program Sekolah Pascasarjana, Universitas Muhammadiyah Surakarta, Indonesia \\ ${ }^{1, *}$ Pos-el Korespondensi: niviaprj@gmail.com \\ ${ }^{2}$ Pos-el: atiqa.sabardila@ums.ac.id \\ ${ }^{3}$ Pos-el:markhamah@ums.ac.id
}

\begin{abstract}
This study aims to identify and describe the prior text used as a reference text in writing the title Program Kreatifitas Mahasiswa 5 in the Field of Funding for the 2018 Fiscal Year. This research belongs to qualitative descriptive research that is naturalistic in nature. The data source used in this study is in the form of Program Kreatifitas Mahasiswa Title 5 Fields funded in 2018. The data generated in the form of words and sentences contained in the data source is Title Program Kreatifitas Mahasiswa 5 in Funding Budget Year 2018. Data analysis methods in the form of translational matching methods, abductive inference methods, and the referential equivalent method. Test the validity of the data using theory triangulation. The results of the study found the writing of Program Kreatifitas Mahasiswa Title 5 in Funding for the Fiscal Year 2018 is a transformation or adaptation text that utilizes several names of characters, including: (1) the names of public figures; (2) the name of the hero; (3) the name of an animated or fictional character; and (4) the name of the artist. The findings in this study indicate that the name of the artist as a reference text has a high appeal to attract readers.
\end{abstract}

Keywords: name of character, Program Kreatifitas Mahasiswa's title, prior text

Abstrak: Penelitian ini bertujuan untuk mengidentifikasi dan mendeskripsikan prior text yang digunakan sebagai teks acuan dalam penulisan judul PKM 5 Bidang Pendanaan Tahun Anggaran 2018. Penelitian ini tergolong dalam penelitian deskriptif kualitatif yang bersifat naturalistik. Sumber data yang digunakan dalam penelitian ini berupa Judul PKM 5 Bidang yang didanai tahun 2018. Data yang dihasilkan berupa kata dan kalimat yang terdapat pada sumber data yaitu Judul PKM 5 Bidang Pendanaan Tahun Anggaran 2018. Metode analisis data berupa metode padan translasional, metode abduktif inferensi, dan metode padan referensial. Uji keabsahan data menggunakan triangulasi teori. Hasil penelitian ditemukan penulisan Judul PKM 5 Bidang Pendanaan Tahun Anggaran 2018 merupakan teks transformasi atau teks saduran yang memanfaatkan beberapa nama tokoh, diantaranya: (1) nama tokoh publik; (2) nama tokoh pahlawan; (3) nama tokoh animasi atau fiksi; dan (4) nama tokoh seniman. Temuan dalam penelitian ini menunjukkan bahwa nama tokoh seniman sebagai teks acuan memiliki daya tarik yang tinggi untuk menarik pembaca.

Kata kunci: nama tokoh, judul Program Kreativitas Mahasiswa, prior text

\section{A. PENDAHULUAN}

Kreativitas mahasiswa dapat

mempengaruhi perkembangan ilmu

pengetahuan. Hal tersebut dapat dipengaruhi dari berbagai kreativitas dan inovasi yang diciptakan oleh mahasiswa. Salah satu wadah yang dapat dimanfaatkan untuk menampung 
kreativitas mahasiswa, yaitu melalui Program Kreativitas Mahasiswa (PKM). Program ini dirancang oleh Direktorat Jenderal Pembelajaran dan Kemahasiswaan, yang bertujuan untuk membentuk kreativitas atau potensi yang dimiliki oleh mahasiswa.

Ada hal yang menarik dalam PKM, yaitu penulisan judul. Keterampilan dalam menulis judul menuntut kecerdasan dan kreativitas penulis, karena mustahil bagi penulis akan menghasilkan karya yang menarik apabila tidak mengasah proses kreatif secara terus-menerus (Halijah et al., 2020).

Judul merupakan gambaran secara umum mengenai bagian inti yang disampaikan dalam PKM, yang digunakan untuk menarik pembaca. Dalam penulisan judul PKM tentu akan dibuat semenarik mungkin. Kemenarikan penulis dalam membuat judul tentu tidak terlepas dari kemampuan berpikirnya, karena kemampuan berpikir seseorang dapat dilihat dari penggunaan bahasanya (Ainin et al., 2019).

Judul yang menarik dan unik beda dari yang lainnya tentu menjadi daya tarik pembaca untuk menikmati tulisan yang disajikan oleh penulis. Selain sebagai daya tarik baca, pemilihan kata yang tepat mampu mewakili apa yang ingin disampaikan penulis kepada pembacanya (Syamsiyah \& Rosita, 2020). Salah satu hal yang menarik dalam penulisan Judul PKM 5 Bidang Pendanaan Anggaran Tahun 2018, yaitu (prior text) yang dijadikan sebagai acuan dalam penulisan teks yang ada saat ini (present text).

Prior text disebut juga dengan istilah intertextuality. Prior text merupakan teks lain atau teks yang sudah ada sebelum teks yang ada saat dibuat. Teks dibuat dari teks lain atau disebut juga dengan intertekstualitas (Lemke, 2000). Intertekstualitas menghargai pengambilan, penyerapan, maupun pemasukan teks-teks lain ke dalam teks yang dihadirkan penulis baik secara sadar ataupun tidak sadar (Kristeva et al., 1982). Karena teks yang ada saat ini tentu mendapat pengaruh dari teks-teks yang sudah ada sebelumnya.

Pemahaman intertekstualitas berkaitan dengan proses pembacaan, yaitu prinsip penemuan kembali, prinsip membuat sesuatu yang semula asing menjadi biasa, prinsip integrasi satu teks dengan teks lain, dan prinsip penyesuaian (Ratna, 2005).

Setiap teks lahir tidak pernah sepenuhnya steril dari adanya keberadaan teks lain (Hasbullah, 2014). Fenomena ini sebagai langkah dalam menghargai adanya penyerapan, pengambilan, dan pemasukan teks lain ke dalam teks yang dihadirkan penulis baik secara sadar ataupun tidak sadar dalam dunia wacana yang sesungguhnya bersifat klasik.

Hal ini dapat dinyatakan adanya hubungan ketergantungan satu teks dengan teks-teks lain sebelumnya (Denissa et al., 2016). Intertekstualitas dijadikan sebagai mode of reading alternatif di dalam melakukan kerja analisis teks atau membaca fenomena kewacanaan sekarang (Hasbullah, 2014).

Becker (dalam Gordon, 2006) memperkenalkan prior text menyatakan bahwa teks yang sudah ada sebelumnya atau teks lama berperan untuk membentuk teks baru. Ada teks yang di konstruksi sebagai mosaik dari kutipan, teks tersebut merupakan proses dari penyerapan dan transformasi teks orang lain. Karena teks pendahulu (prior text) mempunyai peranan yang penting dalam menciptakan teks yang ada saat ini (present text) (Kristeva dalam Denissa et al., 2016).

Intertekstualitas tidak hanya melihat sebuah teks melalui kemunculannya dari teks sosial, namun juga kelanjutan keberadaan teks tersebut di dalam masyarakat dan sejarah (Kuswarini, 2016). Hal ini menimbulkan persepsi bahwa penciptaan teks yang ada saat ini (present text) memerlukan latar belakang 
pengetahuan mengenai teks-teks yang sudah ada sebelumnya.

Hal ini tidak dinyatakan sebagai suatu penyimpangan dalam penulisan sebuah teks (Teeuw dalam Putri, 2010). Ciri intertekstualitas adalah adanya ketergantungan satu teks dengan teks-teks yang sudah ada sebelumnya dalam bentuk persilangan berbagai ungkapan dan kutipan yang saling mengisi (Piliang dalam Denissa et al., 2016).

Intertekstualitas digolongkan menjadi dua, yaitu intertekstualitas horizontal dan intertekstualitas vertikal (Fiske, 1987). Namun, dalam penelitian ini hanya dibatasi dengan menggunakan intertekstualitas vertikal. Intertekstualitas vertikal yaitu intertekstualitas yang memperlihatkan adanya hubungan atau interaksi pada jenis referensi yang berbeda. Melihat adanya keterkaitan teks berita dengan teks atau peristiwa yang tidak memiliki hubungan dengan peristiwa, misal puisi, film, novel/cerpen, lukisan/sketsa, pidato tokoh, dongeng, kepercayaan (takhayul), kisah populer di masyarakat, dan lain sebagainya.

Dari beberapa teori di atas dapat ditarik simpulan bahwa prior text atau intertekstualitas sebagai suatu fenomena adanya hubungan atau keterkaitan antara teks yang ada saat ini (present text) dengan teks yang sudah ada sebelumnya atau terdahulu (prior text). Penelitian ini menggunakan teori John Fiske, mengenai intertekstualitas vertikal yang melihat adanya interaksi teks terdahulu (prior text) yang mengacu pada nama tokoh.

Penelitian yang berkaitan dengan prior text (intertekstualitas) telah dilakukan oleh peneliti sebelumnya, berikut penelitian-penelitian terdahulu yang berkaitan dengan prior text (intertekstualitas). Al-Ma'ruf (2005) menemukan adanya hubungan intertekstualitas pada puisi Padamu Jua karya Amir Hamzah yang dijadikan sebagai hipogram pada puisi Doa karya Chairil Anwar. Hubungan intertekstualitas pada kedua puisi bersifat inovatif, karena dipengaruhi oleh latar belakang penyair masing-masing.

Septiyani \& Sayuti

menemukan aposisi (pertentangan antara dua hal yang tidak dapat dipersatukan kembali) dalam novel Rahuvana Tattwa karya Agus Sunyoto. Novel ini lahir sebagai penentang cerita-cerita Ramayana yang sebelumnya sudah ada. Oposisi di antara keduanya terdapat pada sistem kekerabatan, sesembahan, dan peradaban.

Panuju (2019) menemukan adanya intertekstualitas dalam video berjudul Jangan Panggil Aku Cina pada kolom komentar di Youtube. Hubungan intertekstualitas ditekankan pada model permutasi teks dengan hasil analisis bahwa adanya pandangan stereotip dan prasangka sehingga menempatkan etnis Cina sebagai etnis yang buruk.

Sari \& Samsiarni (2017) mengungkapkan bahwa komik Labirnya Bangbang Wisanggeni karya R. A. Kosasih merupakan hipogram dari novel Wisanggeni Sang Buronan karya Seno Gumira Adjidarma. Hubungan intertekstualitas terjadi pada tokoh Wisanggeni di dalam novel yang dihadirkan dengan sosok yang berbeda dari cerita dalam komik.

Kusuma et al. (2018) menemukan bahwa novel Pasung Jiwa karya Okky Madasari merupakan hipogram dari novel Calabai karya Pepi Al-Bayqunie sebagai teks transformasi. Persamaan tema, penokohan, dan peristiwa-peristiwa menunjukkan adanya hubungan intertekstualitas di antara keduanya. Sedangkan untuk alur dan latar dalam novel Calabai menyimpang dari hipogramnya.

Putra \& Sari (2019) menemukan adanya hubungan intertekstual dalam ungkapan sastra Bali modern dengan karya sastra atau kitab-kitab agama. Selain itu, hubungan interteks juga secara implisit terdapat dalam ungkapan bahasa Indonesia. Dengan kata lain bahwa 
ungkapan kearifan lokal Bali memiliki sinonim dengan bahasa Indonesia.

Fatmawati (2019) membuktikan teori Julia Kristeva bahwa tidak ada teks yang berdiri sendiri atau tidak mendapat pengaruh dari teks lain. Dapat dilihat dalam analisis, yaitu adanya hubungan intertekstualitas dalam kitab Tafsir Al-Qur'an Al-Azim karya Ibnu Katsir dengan kitab Tafsir Al-Jami' Li Abkam alQur'an karya Qurthubi, Tafsir Ibnu Mas'ud karya Ibn Mas'ud, dan Tafsir Jami' al bayan an ta'wil ay al-Quran karya Thabari.

Thielemann (2020) menemukan adanya hubungan intertekstual dalam percakapan bahasa Rusia. Percakapan non-formal yang dapat dipahami dengan adanya referensi konteks yang terjalin oleh penutur dan mitra tutur. Perlu adanya pemahaman mengenai konteks yang sudah terjadi sebelumnya sehingga percakapan dapat terjalin dengan baik.

Kuleli (2014) menganalisis intertekstualitas dalam novel Sessiz karya Orhan Pamuk (1983) dengan produk terjemahan karya Finn (2012). Hasil analisis ditemukan adanya bagian-bagian tertentu yang diterjemahkan secara berlebihan dari teks yang dijadikan hipogram. Amicucci (2020) melakukan eksperimen kepada dua mahasiswa dalam melakukan penulisan identitas di akun jejaring sosial Facebook melalui intertekstualitas.

Denissa et al. (2016) mengkaji fenomena intertekstualitas fashion karnaval yang ada di Nusantara. Hasil penelitian menunjukkan bahwa prinsip intertekstualitas pada seni merupakan fenomena pertumbuhan seni yang sudah ada sejak dahulu di Nusantara. Jember Fashion Carnaval adalah produk intertekstualitas terhadap fashion dan karnaval-karnaval besar dunia yang telah eksis sebelumnya.

Gordon (2006) mengkaji reshaping prior text, reshaping identities atau membentuk kembali teks sebelumnya dan membentuk kembali identitas. Hasil kajian diperoleh bahwa pembentukan kembali teks sebelumnya berfungsi sebagai sumber daya untuk membuat berbagai identitas di interaksi yang berbeda dan untuk pemirsa yang berbeda melalui konstruksi keberpihakan atau pijakan. Analisis menunjukkan beberapa spesifikasi, seperti: teks; kata-kata khusus dan rangkaian kata; tindak tutur dan kontekstualisasi; isyarat seperti tawa, nada tinggi.

\section{B. METODE}

Jenis penelitian ini adalah penelitian deskriptif kualitatif. Penelitian yang dilakukan pada kondisi alamiah atau natural setting hal ini disebut dengan penelitian yang bersifat naturalistik. Pendekatan yang digunakan dalam penelitian ini berupa historis komparatif.

Subjek dalam penelitian ini adalah Judul PKM 5 Bidang yang didanai Tahun Anggaran 2018. Objek dalam penelitian ini adalah prior text. Teknik pengumpulan data menggunakan teknik simak dan catat. Dengan uji keabsahan data dalam penelitian ini menggunakan triangulasi teori. Peneliti memeriksa keabsahan data menggunakan berbagai cara pandang untuk menginterpretasikan data.

Metode analisis data berupa metode padan translasional, metode abduktif inferensi, dan metode padan referensial untuk mengidentifikasi teks pendahulu (prior text) dalam penulisan judul PKM 5 Bidang yang didanai Tahun Anggaran 2018. Metode abduktif inferensi (abductive inferences) digunakan untuk menarik kesimpulan dengan menghubungkan teks satu dengan teks lain (Krippendorff, 2004).

Metode padan translasional alatnya yaitu organ wicara. Dalam kaitannya dengan pembentukan satuan lingual dapat dibedakan berturut-turut menjadi: bunyi vokal, bunyi konsonan, silabe, kata, kalimat, dan dapat pula wacana. Hal ini akan kelihatan bahwa organ wicara dapat 
berbeda-beda dalam mengaktifkan bagian-bagiannya.

\section{PEMBAHASAN}

Penulisan judul PKM 5 bidang pendanaan tahun anggaran 2018 memiliki hubungan intertekstualitas dengan nama tokoh. Dapat dikatakan bahwa nama tokoh memiliki andil sebagai hipogram yang dijadikan sebagai acuan dalam penulisan judul PKM. Salah satu strategi untuk memperkenalkan produk baru kepada masyarakat, yakni memilih namanama yang sudah mereka kenal sebelumnya agar produk itu segera bisa diingat. Fiske (1987) pemilihan tokoh ada beberapa hal yang perlu untuk dijadikan pertimbangan, di antaranya: aspek popularitas; memiliki pengaruh; kontroversial; dan memiliki keunikan.

Data yang menunjukkan teks terdahulu (prior text) dalam penulisan Judul PKM 5 Bidang untuk Pendanaan Tahun Anggaran 2018 sebanyak 10 wujud nama tokoh. Penelitian ini menggunakan teori Fiske (1987) mengenai intertekstualitas vertikal. Melihat adanya interaksi teks terdahulu (prior text) yang berupa nama tokoh yang diacu oleh teks yang ada saat ini (present text) pada penulisan judul PKM 5 bidang.

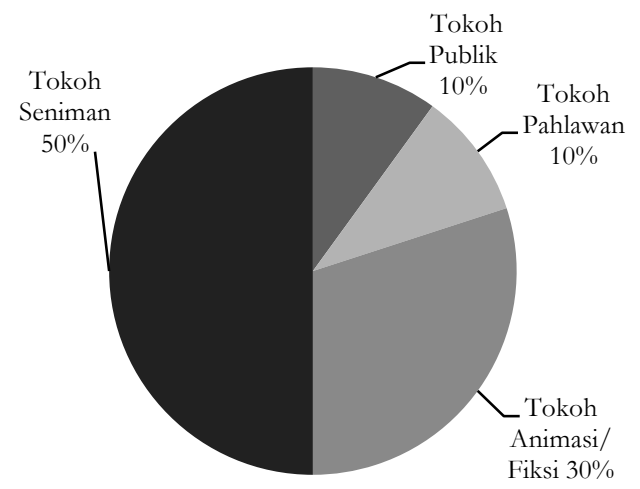

\section{Gambar 1. Nama Tokoh sebagai Prior Text pada Judul PKM 5 Bidang Tahun 2018}

Berdasarkan identifikasi data prior text dalam judul PKM 5 bidang untuk pendanaan tahun anggaran 2018 dikelompokkan menjadi 4 nama tokoh, meliputi: (1) nama tokoh publik; (2) nama tokoh pahlawan; (3) nama tokoh animasi/fiksi; dan (4) nama tokoh seniman.

\section{Prior Text Berupa Nama Tokoh Publik}

Penggunaan nama tokoh publik sebagai latar belakang dari pembuatan Judul PKM berfungsi sebagai daya tarik pembaca. Dalam hal ini Judul PKM berperan sebagai teks transformasi atau teks saduran, sedangkan untuk nama tokoh publik berperan sebagai teks acuan. Berikut ini data yang menunjukkan nama tokoh publik sebagai teks acuan dalam penulisan Judul PKM.

(1) ANTASARY (Perancangan dan Implementasi WSN Pada Smart Fishery) $(041027 / 2018 /$ PKMKC)

Data (1) merupakan judul PKM 5 Bidang Pendanaan 2018 yang dilatarbelakangi oleh nama tokoh publik yang terkenal di Indonesia, Antasari Azhar. Hal ini dapat dilihat pada tokoh Antasari Azhar yang merupakan tokoh publik terkenal seorang mantan Ketua Komisi Pemberantasan Korupsi (KPK).

Antasari Azhar mempunyai segudang prestasi dalam kariernya di kejaksaan. Dimulai sejak tahun 1981 sebagai Diplomat di BPHN Departemen Kehakiman, tahun 1985 sebagai Jaksa Fungsional, Kasi Penyidikan Korupsi Kejaksaan Tinggi Lampung tahun 1992, Kasi Pidana Khusus Kejaksaan Negeri Jakarta Pusat pada tahun 1994, Kepala Kejaksaan Negeri Baturaja pada tahun 1997. Hingga pada tahun 2000 Antasari Azhar melanjutkan kariernya di jajaran 
Kejaksaan Agung sebagai Kepala Kejaksaan Negeri Jakarta Selatan ${ }^{1}$.

Penggunaan Judul PKM ini merujuk pada gambaran inovasi yang digagas oleh mahasiswa Universitas Komputer Indonesia. Inovasi ini merupakan perancangan dan implementasi dari WSN atau Wireless Sensor Network yang dapat dimanfaatkan para nelayan untuk meningkatkan hasil tangkapan ikan di laut. Memiliki persamaan nama menjadikan Judul PKM pada data (1) merujuk pada nama tokoh publik Antasari Azhar yang dijadikan sebagai prior text. Dapat dilihat secara saksama konten keduanya memiliki kemiripan.

Peningkatan karier Antasari Azhar selaras dengan judul PKM “ANTASARY (Perancangan dan Implementasi WSN pada Smart Fishery)". Hal ini dapat dilihat dari adanya peningkatan kegunaan WSN untuk diimplementasikan pada smart fisrery. Sedangkan pada nama tokoh yang dijadikan rujukan pada penulisan judul PKM, menggambarkan mengenai karier seorang tokoh Antasari Azhar yang kian meningkat. Dapat disimpulkan bahwa Judul PKM “ANTASARY” merupakan teks transformasi atau teks saduran dari nama tokoh publik terkenal Antasari Azhar.

Penulisan judul PKM dilakukan dengan proses transformasi. Seperti pemahaman dari Ahimsa Putra yang dikutip oleh (Zuriati, 2011) bahwa proses transformasi ada dengan perubahan yang struktur luar namun makna atau pesan yang ingin disampaikan tetap sama. Dalam hal ini proses transformasi dilakukan dengan cara melesapkan suku kata pada setiap fonem. Pada nomina $\boldsymbol{A N}$-TA $\boldsymbol{A} \boldsymbol{S A}-\boldsymbol{R} \boldsymbol{Y}$ merupakan gabungan dari pelesapan setiap suku kata, yaitu pada frasa nomina Perancangan-ImplementasiSmart-Fishery.

1 https://www.bbc.com/indonesia/trensosial3896851919 Desember 2019, pukul 10:15 WIB

\section{Prior Text Berupa Nama Tokoh Pahlawan}

Nama tokoh pahlawan sebagai sumber inspirasi dala penulisan Judul PKM. Hubungan intertekstualitas jelas terlihat diantara Judul PKM dan nama tokoh pahlawan yang disini berfungsi sebagai teks acuan. Dapat dikatakan bahwa penggunaan nama tokoh pahlawan disebut dengan prior text atau teks acuan dan Judul PKM disebut dengan present text atau teks transformasi.

(2) "Kartini": Karbon Aktif Penjernih Minyak Goreng Habis Pakai Berbasis Limbah Kulit Pisang yang Ekonomis dan Ramah Lingkungan (001041/2018/PKMKC)

Penggunaan nomina Kartini pada Judul PKM data (2) merujuk pada inovasi yang memanfaatkan bahan alami ramah lingkungan untuk menjernihkan minyak goreng. Sebuah karya hasil gagasan dari empat mahasiswa Unnes ini berhasil mendapatkan emas dalam ajang PIMNAS ke-31.

Produk yang diberi nama Kartini merupakan sebuah inovasi baru yang layak untuk diapresiasi ${ }^{2}$. Ke-4 mahasiswa berhasil menciptakan sebuah produk yang berfungsi untuk menjernihkan minyak goreng yang telah digunakan dengan karbon aktif dan memanfaatkan bahan alami ramah lingkungan, yaitu limbah kulit pisah.

Judul PKM tersebut jelas sebagai teks transformasi atau teks saduran dari salah satu nama tokoh pahlawan perempuan Indonesia, Raden Ayu Kartini yang terkenal akan karyanya yaitu Habis Gelap Terbitlah Terang. Raden Ayu Kartini lahir pada 21 April 1879. Salah satu pahlawan perempuan Indonesia yang memiliki misi ikut andil dalam berperan aktif memperjuangkan emansipasi

\footnotetext{
${ }^{2}$ http://ft.unnes.ac.id/?p=6006 17 Maret 2020 pukul 09:56 WIB
} 
wanita. Menjernibkan pemikiran wanita untuk memperoleh kekuasaan dan persamaan hukum. Wanita juga berhak memiliki kebebasan dalam menuntut ilmu ${ }^{3}$.

Hubungan intertekstualitas di antara keduanya dapat dirunut berdasarkan sikap Kartini yang turut berperan aktif dalam menjernihkan pemikiran kaum wanita agar menjadi wanita yang memiliki kebebasan dan persamaan hak dengan kaum laki-laki. Dapat dikatakan juga bahwa wanita itu bukan kaum lemah, hidupnya tidak hanya bergantung pada kaum pria, dan tidak hanya narimo (Suarniti, 2017). Hal ini selaras dengan misi penulisan Judul PKM yaitu dalam perannya untuk menjernibkan minyak goreng habis pakai.

Selain memiliki persamaan misi, penggunaan nama Kartini dalam judul PKM dan nama tokoh pahlawan memiliki perbedaan yang mencolok. Perbedaan tersebut terletak pada jenis keduanya yang berbeda, Kartini dalam judul PKM sebagai inovasi kreatif dalam menjernihkan minyak goreng, sedangkan untuk Kartini yang digunakan sebagai teks acuan adalah sebagai penunjuk nama tokoh pahlawan perempuan Indonesia.

Penulisan judul PKM melalui kreativitas penulis dalam merujuk salah satu nama tokoh pahlawan di Indonesia, yang dilakukan dengan cara melesapkan suku kata. Hal ini dapat dilihat pada pelesapan suku kata pada nomina karbon menjadi kar-bon, adjektiva aktif menjadi ak-ti-f, dan penjernih menjadi penjer-ni-h. Hasil pelesapan didapatkan nomina kartini.

\section{Prior Text Berupa Nama Tokoh Animasi/Fiksi}

Nama tokoh animasi/fiksi digunakan sebagai teks transformasi atau teks acuan dari penulisan Judul PKM. Hal ini sebagai bukti bahwa tidak ada teks yang tidak ${ }^{3}$ https://id.wikipedia.org/wiki/Kartini 17 Maret 2020
pukul 09:58 WIB mendapat pengaruh dari teks lain. Berikut ini data yang menunjukkan nama tokoh animasi/fiksi sebagai prior text.

(3) JAMES BON (Jamur Kremes Abon) (021010/2018/PKMK)

Data (3) menunjukkan judul PKM yang memiliki hubungan dengan nama tokoh fiksi yang terkenal sejak tahun 1962, yaitu James Bond. Judul PKM ini yang menyajikan informasi mengenai inovasi yang diciptakan oleh mahasiswa Universitas Muhammadiyah Bengkulu yang memanfaatkan bekas tandan sawit untuk media tanam jamur. Jamur sawit selanjutnya diolah menjadi jamur kremes abon sebagai variasi dalam mengolah jamur dan memiliki nilai jual tinggi (Astri, 2008).

Dilihat dari konten yang disampaikan kedua teks memiliki kemiripan. Keduanya menunjukkan misi kebaikan dalam menyelamatkan dan memiliki nilai guna lebih. Penggunaan nomina James Bon dalam judul PKM menunjukkan misi untuk menyelamatkan bekas tandan sawit yang terbuang sia-sia. Selanjutnya bekas tandan sawit dimanfaatkan sebagai media tanam jamur dan hasil panen jamur diolah menjadi sajian makanan jamur kremes abon yang memiliki nilai lebih.

Hal ini sesuai dengan misi yang dibawa oleh tokoh fiksi James Bond dalam setiap aksinya, yaitu untuk menyelamatkan bumi dari kejahatan manusia sebagai seorang agen intelijen dunia atau seorang mata-mata ${ }^{4}$. Berdasarkan uraian tersebut, James Bon pada judul PKM mengarah pada gambaran aksi untuk menyelamatkan limbah sawit yang sebelumnya hanya dibuang dan menimbulkan tumpukan sampah kini dapat bermanfaat.

Judul PKM ini dibuat dengan melesapkan suku kata yang mengacu pada nama tokoh James Bon. Pelesapan

\footnotetext{
4 https://id.wikipedia.org/wiki/James_Bond 19 Maret 2020 pukul 12:17 WIB
} 
terlihat pada pola konsonan-vokal (KV) pada nomina jamur menjadi ja-mur. Pola konsonan-vokal-konsonan (KVK) nomina kremes menjadi kre-mes dan pola nomina abon menjadi a-bon. Hal ini dapat dilihat pada penelitian (Zuriati, 2011) yang menyatakan bahwa suku kata terdiri dari fonem-fonem dan dibentuk oleh vokal maupun kombinasi dari vokalkonsonan yang biasa disebut dengan (VK). Satu suku kata harus terdiri dari sebuah bunyi vokal.

(4) PETRIK (Perangkat Tanam Organik): Ekspansi Bisnis Kreatif dan Futuristik dalam Mewujudkan Urban Farming Berkelanjutan dengan Inovasi Media Tanam Berbasis Limbah Batang Pisang dengan Teknologi Pengolahan Sterilisasi (001019/2018/PKMK)

Data (4) menunjukkan judul PKM merujuk pada inovasi dalam memanfaatkan limbah batang pisang sebagai media tanam berbasis organik dengan memanfaatkan teknologi pengolahan sterilisasi. Inovasi ini mengusung konsep limbah batang pisang yang dimanfaatkan sebagai media tanam. Hal ini sebagai sebuah terobosan berkelanjutan dari urban farming dengan memajukan bisnis kreatif.

Penulisan judul PKM ini sebagai teks rujukan atau transformasi pada salah satu tokoh animasi yang berhubungan dengan organisme hidup atau organik, yaitu Patrick Star. Hal ini disandingkan dengan media tanam limbah batang pisang berbasis organik. Konten keduanya memiliki keterkaitan, yaitu sama-sama menggambarkan "organisme hidup atau organik" (KBI Daring, 2019). Tokoh patrick star merupakan karakter dari animasi Spongebob yang diceritakan sebagai organisme bintang laut ${ }^{5}$.

${ }^{5}$ https://id.wikipedia.org/wiki/Patrick Star 19 Maret 2020 pukul 12:22 WIB

Penulisan judul PKM pada data (6) dilakukan dengan cara melesapkan suku kata pada pola konsonan-vokalkonsonan-konsonan-konsonan-vokal-

konsonan (KVKKKVK) nomina Perangkat menjadi Pe-rangkat. Pola vokal-konsonan-vokal-konsonan

(VKVK) pada nomina tanam menjadi $\boldsymbol{t}$ anam dan pola vokal-konsonan-vokalkonsonan (VKVK) pada nomina organik menjadi o-r-gan-ik, hasil pelesapan tersebut menjadi suku kata trik. Gabungan dari pelesapan suku kata pada setiap nomina menjadi petrik.

(5) MONOLISA Bahasa) sebagai Media Alternatif dalam Meningkatkan Kemampuan Berpikir Kreatif Siswa Tuna Rungu di SLB Negeri Semarang (001041/2018/PKMM)

Tim PKM dari Unnes berhasil membuat sebuah inovasi baru berupa media pembelajaran yang dinamakan monolisa (monopoli bahasa). Sebuah media pembelajaran yang dibuat khusus untuk siswa tunarungu dalam membantu proses kegiatan pembelajaran yang berkaitan dengan bahasa.

Dapat dikatakan bahwa pemerolehan bahasa pada anak adalah suatu proses belajar, dalam hal ini stimuli verbal dan nonverbal dari luar membentuk kondisi untuk proses belajar tersebut (Akbar, 2015). Media ini memiliki peranan yang cukup signifikan. Monolisa (monopoli bahasa) tentu mengedepankan kesantunan dalam berbahasa yang meliputi enam maksim, yaitu: kebijaksanaan, penghargaan, kedermawanan, kerendahan hati, simpati, dan kecocokan (Suarniti, 2017).

Dalam kegiatan PKMM di SLB Negeri Semarang selain menciptakan media, kegiatan juga meliputi pembuatan desain dan pemberian pelatihan untuk menggunakan media pembelajaran monolisa tersebut. Tujuan dari 
pembuatan media monolisa yaitu untuk membantu siswa dalam proses pembelajaran untuk ikut serta dalam berpikir kreatif dan aktif ${ }^{6}$.

Penulisan judul PKM pada data (5) merupakan teks transformasi dari nama tokoh fiksi Mona Lisa, yaitu nama atau judul dari lukisan yang dibuat oleh Leonardo da Vinci. Pemilihan nama tokoh atau judul lukisan ini menggambarkan seorang wanita bernama Lisa Gherardini. Berdasarkan penelusuran, mona merupakan singkatan dari madonna yaitu nomina yang diambil dari bahasa Italia dengan makna nyonyaku.

Lukisan ini juga diberi nama lain, yaitu La Gioconda yang artinya menggambarkan senyum wanita riang yang ada di dalam lukisan. Selain itu lukisan tersebut disebut juga dengan judul wanita dari Firenze atau wanita bangsawan yang menggunakan kerudung tipis. Berdasarkan penjelasan tersebut, pemilihan nama Mona Lisa dalam judul lukisan merupakan permainan bahasa untuk menggambarkan makna dari lukisan tokoh fiksi tersebut ${ }^{7}$.

Hal ini sesuai dengan makna judul PKM pada data (5) di atas. Penggunaan judul PKM menjelaskan media pembelajaran yang berupa permainan monopoli bahasa untuk meningkatkan kemampuan berpikir kreatif siswa tuna rungu. Sedangkan tokoh fiksi yang diberi nama Mona Lisa merupakan permainan bahasa dalam menyampaikan makna tokoh fiksi tersebut. Dapat dikatakan bahwa berdasarkan konten keduanya memiliki kemiripan yaitu sama-sama menggambarkan mengenai permainan bahasa.

Penulisan judul PKM ini mengalami perubahan fonem, yakni pada nomina mona lisa menjadi monolisa. Terjadi perubahan fonem " $\boldsymbol{a}$ " menjadi fonem

${ }^{6}$ https://www.suaramerdeka.com/smcetak/baca/ 97978/ciptakan-monolisa-untuk-siswa-tunarungu 19 Maret 2020 pukul 12:38 WIB

7 https://id.wikipedia.org/wiki/Mona_Lisa 24 Maret 2020 pukul 10:53 WIB
" $\boldsymbol{o}$ ". Selain itu nomina MONOLISA merupakan hasil dari pelesapan suku kata, yaitu pelesapan pola konsonan-vokal (KV) pada nomina monopoli menjadi mono-po-li. Dan pelesapan pola konsonan-vokal-konsonan-vokal (KVKV) pada nomina bahasa menjadi baha-sa.

\section{Prior Text Berupa Nama Tokoh Seniman}

Penggunaan nama tokoh seniman sebagai latar belakang penulisan Judul PKM. Hal ini dikarenakan keberadaan nama tokoh seniman sudah ada terlebih dahulu daripada Judul PKM, sehingga dapat dikatakan bahwa keberadaan Judul PKM sebagai teks yang dipengaruhi oleh keberadaan teks yang ada sebelumnya. Berikut ini data yang menunjukkan nama tokoh seniman sebagai prior text.

\section{(6) Donat Sushi "Doshi" Usaha Sushi Kekinian Berbentuk Donat (033066/2018/PKMK)}

Data (6) menunjukkan judul PKM Pendanaan 2018 yang dilatarbelakangi dari hasil kreativitas dalam usaha sushi kekinian yang dibuat dalam bentuk menyerupai donat. Judul PKM pada data (6) merupakan teks transformasi dari salah satu nama tokoh seniman, yaitu Balkrishna Vithaldas Doshi, seorang arsitek terkenal asal India. Penggunaan nama tokoh seniman Balkrishna Vithaldas Doshi dijadikan sebagai teks acuan atau prior text dan Judul PKM Doshi sebagai teks transformasi atau disebut dengan present text.

Apabila dilihat dari konten keduanya, yaitu antara teks acuan dan teks transformasi memiliki kemiripan perihal keativitas. Tokoh Balkrishna Vithaldas Doshi, seorang arsitek yang lahir pada tahun 1927. Ia terkenal akan kreativitasnya dalam arsitektur bahkan ia disebut sebagai arsitektur modern di India yang mendapatkan penghargaan pada tahun 
$2018^{8}$. Sedangkan pada judul PKM Donat Sushi "Doshi" merupakan inovasi yang kreatif dalam menggabungkan dua konsep makanan yaitu donat dan sushi menjadi satu hidangan baru yang kreatif dan belum banyak dibuat orang.

Judul PKM Donat Sushi "Doshi" sebagai present text yang merujuk pada nama tokoh Balkrishna Vithaldas Doshi yang dijadikan prior text. Proses transformasi dilakukan dengan melesapkan suku kata pada setiap kata di judul PKM, yaitu pelesapan pola konsonan-vokal-konsonan (KVK) pada nomina donat menjadi do-nat dan pola konsonan-vokal (KV) nomina sushi menjadi su-shi.

(7) Jastin Biber (Jas Hujan Nyentrik Bikin Baper) Harta Karun di Balik Sampah (031021/2018/PKMK

Judul PKM pada data (7) ini menggambarkan kreativitas dalam mengolah sampah plastik menjadi barang baru yang memiliki nilai jual yang tinggi. Sampah plastik yang didaur ulang dengan ditambahkan kreativitas akan menghasilkan produk yang tidak kalah dengan kualitas produk pabrik. Pengolahan limbah plastik selain untuk menghasilkan produk yang bernilai jual tinggi juga dapat menyelamatkan alam dari timbunan sampah yang sulit terurai.

Pemilihan judul PKM "Jastin Biber (Jas Hujan Nyentrik Bikin Baper)" sebagai teks hasil transformasi pada nama tokoh seniman terkenal yang sukses berprestasi dalam kreativitasnya di industri musik, yaitu Justin Bieber. Ia juga terkenal sebagai sosok yang memiliki penampilan dan karisma yang menarik dalam setiap aksi panggungnya. Hal ini menjadi daya

${ }^{8}$ https://translate.google.com/translate?hl=id\&sl= en\&u=https://en.wikipedia.org/wiki/B. V. Doshi\&pr ev $=$ search pada 24 Maret 2020 pukul 11:08 WIB tarik kaum muda akan prestasi yang ditorehkan oleh Justin Bieber'.

Dilihat dari konten keduanya memiliki keterkaitan, yaitu sama-sama menunjukkan kreativitas. Pada judul PKM yang dijadikan sebagai present text atau disebut juga dengan teks hasil transformasi, menggambarkan kreativitas dalam mengolah limbah plastik menjadi jas hujan nyentrik dan biasanya menjadi mode fashion anak muda yang memiliki daya nilai jual di pasaran. Sedangkan nama tokoh Justin Bieber sebagai prior text atau sebagai teks acuan, digambarkan sebagai sosok penyanyi yang memiliki kreativitas dalam bermusik yang memiliki gaya penampilan menarik dan disukai kaum muda.

Selain dari kontennya, penulisan Judul PKM dapat dilihat dari proses transformasi pelesapan pada setiap suku kata. Pertama pada nomina Jastin merupakan gabungan dari nomina jas dan nyentrik. Selanjutnya pada nomina Biber merupakan gabungan dari pelesapan setiap suku kata, yaitu pola konsonan-vokal-konsonan (KVK) pada nomina Bikin menjadi Bi-kin. Pola vokal-konsonan (VK) pada nomina Baper menjadi $\boldsymbol{B}$-ap-er, yaitu adanya penggantian fonem vokal " $\boldsymbol{u}$ " pada nomina Justin menjadi fonem vokal " $\boldsymbol{a}$ " yaitu Jastin. Pelesapan fonem vokal " $\boldsymbol{e}$ " pada Bieber menjadi Biber.

(8) MeLi GusLow. Kreasi Meja Lipat dari Paralon Bekas Anti Galau (061031/2018/PKMK)

Data (8) merupakan judul PKM yang dilatarbelakangi oleh inovasi pemanfaatan pipa bekas yang dikreasikan menjadi meja lipat. Hal ini merupakan sebuah gagasan baru dalam pemanfaatan paralon bekas yang biasanya tidak digunakan lagi dan hanya sebagai sampah. Dengan mendayagunakan kreativitas,

\footnotetext{
${ }^{9}$ https://id.wikipedia.org/wiki/Justin Bieber pada 25 Maret 2020 pukul 11:07 WIB
} 
barang bekas dapat diubah menjadi barang bernilai guna lebih.

Judul PKM pada data (8) merupakan teks saduran atau teks transformasi dari salah satu nama penyanyi dan pencipta lagu terkenal di Indonesia yang terkenal sejak kemunculannya di jagat musik pada pertengahan tahun 90-an, yaitu Melly Cessy Goeslaw atau kerap dikenal dengan nama Melly Goeslaw ${ }^{10}$.

Penggunaan judul PKM ini mengungkapkan kreativitas dalam pemanfaatan paralon bekas menjadi meja lipat yang tidak membutuhkan dana yang banyak atau lowbudget, oleh karena itu tidak menimbulkan pikiran yang "galau" atau pikiran yang kacau (KBBI Daring, 2019). Dilihat dari konten judul tersebut sesuai dengan tokoh Melly Goeslaw yang memiliki kreativitas tinggi sebagai seorang penyanyi dan pencipta lagu. Ratarata lagu yang diciptakan oleh Melly Goeslaw menggambarkan perasaan galau ala anak remaja.

Penulisan judul PKM menggunakan proses transformasi pelesapan pada setiap suku kata, yaitu pola konsonan-vokal (KV) pada nomina meja menjadi me-ja. Pola konsonan-vokal-konsonan (KVK) pada nomina lipat menjadi lipat. Hasil pelesapan dari kedua nomina tersebut menjadi nomina meli. Sedangkan untuk nomina guslow merupakan kreativitas penulis menggambarkan keadaan seseorang yang tidak perlu galau dalam membuat meja lipat dengan lowbudget. Gabungan nomina meli dan guslow yang merujuk pada nama tokoh penyanyi, yaitu Melly Goeslaw.

(9) Saekoji (Save Kopi Taji): Edukasi Berbasis Lingkungan sebagai Upaya Meningkatkan Kepedulian Petani Desa Taji terhadap Berkelanjutan

Pertanian melalui

${ }^{10}$ https://id.wikipedia.org/wiki/Melly Goeslaw pada 25 Maret 2020 pukul 11:28 WIB
Manajemen Agribisnis Kopi (001019/2018/PKMM)

Data (9) menunjukkan judul PKM yang menggambarkan edukasi kopi berbasis lingkungan. Melalui edukasi ini petani kopi di Desa Koji mendapatkan materi yang berkaitan dengan pengelolaan bisnis kopi. Harapannya dengan pemahaman yang baik mengenai sistem pengelolaan manajemen agribisnis, kepedulian petani kopi terhadap pertanian berkelanjutan di desa Taji semakin meningkat ${ }^{11}$.

Judul PKM data (9) di atas merupakan teks transformasi dari salah satu nama penyanyi rap terkenal di Indonesia, yang dikenal dengan nama panggung Saykoji. Nama tokoh ini (Saykoji) mempresentasikan seorang penyanyi rap dengan nama lahir Ignatius Rosoinaya Penyami yang disingkat Igor. Ia memberikan nama panggung "Saykoji' dengan tujuan untuk memberikan edukasi kepada masyarakat bahwa keberhasilannya saat ini merupakan hasil dari ujian yang ia terima dulu.

Dulu ia diejek karena pendiam dan sulit untuk bergaul, banyak teman yang menjulukinya Psycho. Dari julukan tersebut, nama Saykoji (ejaan bahasa Indonesia untuk nomina Psycho $G$ ) tercipta. Namun itu semua dijadikan sebagai motivasi untuk dirinya dan membuktikan bahwa dirinya bisa dan mampu menjadi orang sukses lewat ejekan yang ia terima dahulu ${ }^{12}$.

Berdasarkan konten yang dibawa oleh Saykoji tersebut memiliki kemiripan dengan penulisan judul PKM data (9), yaitu memiliki misi memberikan edukasi. Pada judul PKM bertujuan untuk memberikan edukasi kepada petani kopi di Desa Taji akan pentingnya manajemen agribisnis untuk mengembangkan potensi

\footnotetext{
11 http://agriwarta.fp.ub.ac.id/saekoji-save-kopi-tajikembalikan-kelestarian-lingkungan-desa-taji/ 25 Maret 2020 pukul 10:43 WIB

12 https://id.wikipedia.org/wiki/Saykoji pada 25 Maret 2020 pukul 10:44 WIB
} 
alam berupa pertanian kopi. Sedangkan misi yang dibawa oleh penyanyi Saykoji yang dijadikan sebagai prior text adalah memberikan edukasi kepada masyarakat bahwa hinaan orang dapat kita jadikan sebagai langkah untuk meraih kesuksesan. Tidak ada alasan bagi siapa saja untuk meraih sukses.

Penulisan judul PKM ini melalui proses transformasi dengan melesapkan setiap suku kata, pertama melesapkan konsonan " $v$ " pada nomina save menjadi sa-v-e. Kedua, pelesapan pada pola konsonan-vokal (KV) pada nomina kopi menjadi ko-pi. Ketiga, juga melesapkan pola konsonan-vokal (KV) pada nomina taji menjadi ta-ji. Hasil pelesapan setiap suku kata didapat nomina sae-ko-ji dengan dibaca saekoji.

(10) Sandra Dewi (Sabun Kertas Anredera dengan Antibakteri) Inovasi Olahan Berbasis Nature Product Modified untuk Mencegah Bakteri (064159/2018/PKMK)

Data (10) menunjukkan judul PKM yang menggambarkan pemanfaatan daun binahong (Anredera cordifolia) yang digunakan sebagai bahan dasar pembuatan sabun. Sabun ini berbentuk selebaran seperti kertas yang berfungsi untuk mencegah bakteri. Sabun dengan model kertas yang diambil dari khasiat daun binahong (Anredera cordifolia) ini merupakan terobosan baru yang berbasis Nature Product Modified. Penulisan judul PKM data (10) ini sebagai teks saduran pada salah satu nama artis terkenal di Indonesia, yaitu Sandra Dewi atau dengan nama lahir Monica Nicholle Sandra Dewi Gunawan Basri.

Dilihat dari konten yang dibawa pada Judul PKM dan nama artis Sandra Dewi memiliki kemiripan. Keduanya menunjukkan kemiripan dalam hal kebersihan. Transformasi yang diterapkan dalam judul PKM ini yang dilatarbelakangi nama Sandra Dewi untuk menggambarkan inovasi baru sabun berbahan dasar Anredera untuk membersihkan dan mencegah adanya bakteri.

Sedangkan konten yang dibawa oleh artis Sandra Dewi yaitu artis yang bersih dari tindakan kriminal, terbukti dari prestasi yang ia torehkan sejak di bangku sekolah maupun kuliah. Ia mengawali karier sebagai Miss Enchanteur 2002 dan duta pariwisata Provinsi Jawa Barat.

Berbagai film dan sinetron juga kerap ia bintangi. Pada tahun 2008 ia dipilih oleh Presiden ke-6 yaitu Susilo Bambang Yudhoyono sebagai Duta Anti Narkoba. Sandra Dewi juga berkecimpung dalam dunia bisnis, yaitu memiliki bisnis produk kecantikan, makanan, pakaian, tas, bisnis propoerti, dan perhiasan ${ }^{13}$.

Penulisan judul PKM dilakukan dengan cara melesapkan suku kata, terlihat pada pola pelesapan konsonanvokal-konsonan (KVK) pada nomina sabun menjadi sa-bun. Pola vokalkonsonan-vokal-vokal (VKVV) pada nomina anredera menjadi a-n-re-d-e-ra. Sedangkan untuk nomina Dewi dalam judul PKM merupakan kreativitas penulis dalam melesapkan konjungsi dengan dan nomina antibakteri. Transformasi hasil pelesapan didapat frasa nomina sandra dewi.

\section{PENUTUP}

Berdasarkan hasil penelitian menunjukkan adanya intertekstualitas antara penulisan Judul PKM 5 Bidang Pendanaan Tahun Anggaran 2018 yang disebut sebagai present text yang dilatarbelakangi dari beberapa nama tokoh yang berperan sebagai prior text, diantaranya: (1) nama tokoh publik; (2) nama tokoh pahlawan; (3) nama tokoh animasi atau fiksi; dan (4) nama tokoh seniman. Nama tokoh yang paling banyak digunakan sebagai teks saduran dalam penulisan Judul PKM adalah nama tokoh seniman. Hal ini menunjukkan bahwa

${ }^{13}$ https://id.wikipedia.org/wiki/Sandra Dewi pada 25 Maret 2020 pukul 10:59 WIB 
nama tokoh seniman sebagai teks saduran memiliki daya tarik yang tinggi untuk menarik pembaca.

\section{DAFTAR PUSTAKA}

Ainin, N., Rokhmansyah, A., \& Purwanti. (2019). Tipe Tuturan Remaja Perempuan Yatim dalam Interaksi Sehari-Hari: Kajian Pragmatik. Diglosia: Jurnal Kajian Bahasa, Sastra, dan Pengajarannya, 2(1), 1-14. https://doi.org/10.30872/diglosia.v $2 \mathrm{i} 1.14$

Akbar, M. A. (2015). Pemerolehan Morfem Afiks Bahasa Indonesia Anak Usia 2-6 Tahun di PAUD Buana Desa Banyu Urip Kabupaten Lombok Tengah. Retorika: Jurnal Ilmu Bahasa, 1(2), 250-257.

Al-Ma'ruf, A. I. (2005). Intertekstualitas Puisi "Padamu Jua" Amir Hamzah dan Puisi "Doa" Chairil Anwar: Menelusuri 'Cahaya' Al-Qur'an dalam Puisi Safistik Indonesia. Kajian Linguistik dan Sastra, 17(32), 75-87.

Amicucci, A. N. (2020). Experimenting with Writing Identities on Facebook through Intertextuality and Interdiscursivity. Computers and Composition, 55, 1-21. https://doi.org/10.1016/j.compcom .2020 .102545

Astri, M. (2008). Analisis Usaha Jamesbon (Jamur Kremes Abon). Jurnal Agribisnis, 11(1), 1429-1436. Retrieved from http://unmuhbengkulu.net/ojs/inde x.php/Agribis/article/download/69 $0 / 147$

Denissa, L., Piliang, Y. A., Widodo, P., \& Adisasmito, N. Y. D. (2016). Fenomena Intertekstualitas Fashion Karnaval di Nusantara. Panggung, 26(4), 430-443. https://doi.org/10.1017/CBO97811 07415324.004

Fatmawati, F. (2019). Penafsiran Sab' Samawat dalam Kitab Tafsir AlQur'an Al-Azim Karya Ibnu Katsir
(Kajian Intertekstualitas Julia Kristeva). Jurnal Ilmiah Ilmu Usbuluddin, 18(2), 124-139. https://doi.org/10.18592/jiiu.v18i2. 3196

Fiske, J. (1987). Television Culture: Popular Pleasures and Politics (Studies in Communication Series). In Methuen \& Co. Ltd. https://doi.org/10.4324/978020383 7153

Gordon, C. (2006). Reshaping prior Text, Reshaping Identities. Text and Talk, 26(4-5), 545-571. https://doi.org/10.1515/TEXT.200 6.022

Halijah, S., Susilo, \& Mulawarman, W. G. (2020). Pengembangan Bahan Ajar Menulis Deskripsi Menggunakan Model Kooperatif Round Table dengan Media Audio pada Siswa Kelas X SMA. Diglosia: Jurnal Kajian Bahasa, Sastra, dan Pengajarannya, 3(2), 115-124. https://doi.org /10.30872/diglosia.v3i2.25

Hasbullah. (2014). Fenomena Intertekstualitas dan Klaim Orisinalitas. Jurnal Ilmu Budaya, 2(2), 377-384.

https://doi.org/10.34050/jib.v2i0.23 83

Krippendorff, K. (2004). Content Analysis: An Introduction to Its Methodology (Second Edition). In Sage Publications. Retrieved from https://login.proxy.libraries.rutgers.e $\mathrm{du} /$ login?url=http:// search.ebscoho st.com/login.aspx?direct $=$ true $\& \mathrm{db}=$ buh\&AN $=48779086 \&$ site $=$ ehost live

Kristeva, J., Roudiez, L. S., Gora, T., \& Jardine, A. (1982). Desire in Language: A Semiotic Approach to Literature and Art. In Poetics Today, 3. https://doi.org/10.2307/1772011

Kuleli, M. (2014). Intertextual Allusions and Evaluation of their Translation in the Novel Silent House by Orhan Pamuk. Procedia - Social and Behavioral 
Sciences, 158, 206-213. https://doi.org/10.1016/j.sbspro.20 14.12.075

Kusuma, K. A., Waluyo, H. J., \& Wardani, N. E. (2018). Pengakuan Calabai: Sebuah Analisis Intertekstual Novel "Pasung Jiwa" Karya Okky Madasari dan Novel "Calabai" Karya Pepi Al-Bayqunie. Kata, 02(01), 50-65. https://doi.org/10.22216/jk.v2i1.31 48

Kuswarini, P. (2016). Penerjemahan, Intertekstualitas, Hermeneutika, dan Estetika Resepsi. Jurnal Administrasi dan Kebijakan Kesehatan Indonesia, 4(1), 39-47.

Lemke, J. L. (2000). Intertextuality and the Project of Ext Linguistics: A Response to de Beaugrande. Text, 20(2), 221-225. https://doi.org/10.1515/text.1.2000. 20.2.221

Panuju, R. (2019). Ajakan Rekonsiliasi yang Bertepuk Sebelah Tangan (Analisis Komentar Video "Jangan Panggil Aku Cina" di Youtube). Komunika: Jurnal Dakwah dan Komunikasi, 13(2), 187-199. https://doi.org/10.24090/komunika .v13i2.1898

Putra, I. N. D., \& Sari, I. A. L. (2019). Mendulang Mutiara Kata: Identifikasi dan Intertektualitas Ekspresi Kearifan Lokal dalam Sastra Bali Modern. Mudra Jurnal Seni Budaya, 34(2), 239-249. https://doi.org/10.31091/mudra.v3 $4 \mathrm{i} 2.706$

Putri, T. H. (2010). Kajian Intertekstualitas dalam Thousand Splendid Suns Karya Khaled Hosseini Terhadap Puisi Kabul Karya Saib-ETabrizi. Diglossia: Jurnal Kajian Ilmiah Kebahasaan dan Kesusastraan. https://doi.org/10.26594/DIGLOS SIA.V1I2.82

Ratna, N. K. (2005). Sastra dan Cultural Studies: Representasi Fiksi dan Fakta.
Yogyakarta: Pustaka Pelajar.

Sari, M. K., \& Samsiarni. (2017). Transformasi Pewayangan Dalam Tokoh Wisanggeni Sebuah Analisis Intertekstual Novel Wisanggeni Sang Buronan Karya Seno Gumira Adjidarma Dengan Komik Lahirnya Bangbang Wisanggeni Karya Ra. Kosasih. Gramatika STKIP PGRI Sumatera Baratm, 3(2), 131-144. https://doi.org/10.22202/jg.2017.v3 i2.1872

Septiyani, V. I., \& Sayuti, S. A. (2019). Oposisi dalam Novel "Rahuvana Tattwa" karya Agus Sunyoto: Analisis Intertekstual Julia Kristeva. Lensa: Kajian Kebahasaan, Kesusastraan, Dan Budaya, 9(2), 174-186. https://doi.org/10.26714/lensa.9.2.2 019.174-186

Suarniti, G. A. M. R. (2017). Pernanan Perempuan dalam Teks Tradisional Bali Geguritan Diah Sawitri. Retorika: Jurnal Ilmu Bahasa, 3(1), 134-144. https://doi.org/10.1017/CBO97811 07415324.004

Syamsiyah, N., \& Rosita, F. Y. (2020). Gaya Bahasa dalam Kumpulan Puisi "Dear You" Karya Moammar Emka. Diglosia: Jurnal Kajian Bahasa, Sastra, dan Pengajarannya, 3(1), 1-13. https://doi.org/10.30872/diglosia.v $3 \mathrm{i} 1.27$

Thielemann, N. (2020). Allusive Talk Playing on Indirect Intertextual References in Russian Conversation. Journal of Pragmatics, 155, 123-134. https://doi.org/10.1016/j.pragma.20 19.10.012

Zuriati. (2011). Transformasi Teks Sutasoma dari Kakawin ke Novel. Literasi, 1(2), 208-219. 